road traffic make this question of great importance, especially at the entrances to the tunnels. The light conditions at these places must be very carefully graded or else the speed of all transport entering the tunnel must be heavily stepped down. . The latter course is objectionable as it interferes with the normal flow over a wide area. He suggests that photo-electric cells might be used to maintain the lighting more constant and so overcome the changing variations of natural light. The photo-cells should be directed towards the ground, since otherwise the effect of sunlight variations is too strong.

\section{Dismantling an Old Colliery}

WE learn from an article in Roads and Road Construction of Lecember 1 that the famous Cymmer Colliery at Porth, Glam., from which coal has been raised for more than a hundred years, has recently ceased work. The immense quantity of plant which it contains is to be dismantled and made available for use either in the coal industry or in similar industries engaged on contracts of national importance. In the history of this colliery, which once employed more than three thousand men and produced more than three thousand tons of coal a day, an interesting story is told of how about fifty years ago, whilst boring in the shaft for piping supports, the men struck what is called a 'gas blower', which is a sort of pocket of free gas. In these days men were permitted to take naked lights down in the cage with them so that they could heat their tea, and one of these lights ignited the natural gas. As it was dangerous to allow such gas to escape into the shaft, a two-inch pipe was installed to conduct it to the surface. Here it has been burning for fifty years without being extinguished. Measurements show that approximately $650 \mathrm{cub}$. $\mathrm{ft}$. per hour was being emitted at the 'blow'. The gas is chiefly methane, and arrangements have now been made to 'bottle' it in steel cylinders at about $800 \mathrm{lb}$. per sq. in. pressure for scientific and industrial use.

Messrs. George Cohen of London and Swansea are at the present time running a 5,000 cub. ft. vertical engine-driven compressor now in the mine to supply air to the haulages for removing the underground plant and machinery, of which there is no less than 4,000 tons, including about 1,200 tons of pit rails. Compressed air was also supplied below for working coal-cutters, jigger conveyors, belt conveyors, and turbine fans. Electric light, both for underground and surface, is supplied by steam-driven generating sets. In 1933 a modern dry coal cleaning plant of 75 tons per hour capacity was installed at a cost of about $£ 20,000$ by the Birtley Iron Co. The roads to the pit are in excellent condition, being supported by about 1,700 tons of steel arches, of which Messrs. Cohen expect to recover about 500 tons.

\section{Hydro-Electric Development in India}

RECENT reports from India, referred to in Beama of November, state that a very large irrigation scheme which will include the generation of large quantities of electric power between the Punjab and the State of Bilaspur is under construction. The volume of water that will be impounded is three times as large as that of the Aswan dam across the Nile. A further scheme for the development of water power utilizes the high run-off of the monsoon rains from the High Range Hills to the plain at Travancore in southern India. Power is obtained from the Munnar River as it descends in a series of cascades from the hills. The monsoon waters are impounded in storage reservoirs built on natural sites. The power station is built on the banks of the river, with the tail-race planned to discharge into it. Above stream, the river water is decanted by a weir, then passes through a channel to the tunnel and forebay. From there it is carried in a $10,000 \mathrm{ft}$. long tunnelan open channel was impracticable owing to the crumbling nature of the surface rock-to the surge tower. Two parallel pipe-lines connect with the power house, each supplying water to a 6,000 brake horse-power turbine.

\section{Weather by Telephone in New York}

AccordIng to the Bell Laboratories Record of November, the New York Telephone Co. inaugurated a new service last April. It is now possible in the Metropolitan area to dial 'weather', and hear the latest weather prediction, including the anticipated temperature, winds, and rain or snow conditions. The bulletins are based on direct teletype reports from the United States Weather Bureau; at present these reports are changed hourly between seven in the morning and eleven at night. When important changes occur, special bulletins may also be given. All the equipment used for this service is installed in the West Fiftieth Street Central Office building, and weather announcing trunk lines are run to all the central offices in Manhattan, while other parts of the metropolitan area reach the announcing bureau through subcentres or tandem offices. In the timeannouncing system a special operator makes each announcement herself. In the weather system use is made of a recorder using magnetic tape. It is well suited for this service as it is necessary to change the recorded message frequently and permanent preservation of the record is of no importance.

The record is made in the usual way by producing, in a moving steel tape, a magnetic pattern corresponding to the voice current coming from the microphone circuit. This pattern remains in the tape and can be 'picked up' electrically many thousands of times before being erased. This is done by saturating the tape with a strong magnetic field. The entire process of erasing, recording a new message and reproducing is controlled by a few keys in the operating turret. No experience or technique is required to obtain exact reproduction of the announcement, and since the steel tape can be used again and again indefinitely, there is no continuing expense for record material and no processing cost involved. Three of these machines are used. The tape machine employs slightly more than $40 \mathrm{ft}$. of tape wound on three brass drums. The two ends of the tape are electrically welded so that it forms a single tape loop. 